\title{
The Literal and the Metaphoric: Paradoxes of Figuration in the Work of Janet Frame
}

\section{Marc Delrez}

\section{(2) OpenEdition \\ 1 Journals}

Electronic version

URL: https://journals.openedition.org/ces/8004

DOI: $10.4000 /$ ces.8004

ISSN: 2534-6695

Publisher

SEPC (Société d'études des pays du Commonwealth)

\section{Printed version}

Date of publication: 1 April 2011

Number of pages: 10-20

ISSN: 2270-0633

\section{Electronic reference}

Marc Delrez, "The Literal and the Metaphoric: Paradoxes of Figuration in the Work of Janet Frame", Commonwealth Essays and Studies [Online], 33.2 | 2011, Online since 18 November 2021, connection on 06 January 2022. URL: http://journals.openedition.org/ces/8004 ; DOI: https://doi.org/10.4000/ ces. 8004

\section{(c) (i) $\odot$}

Commonwealth Essays and Studies is licensed under a Licence Creative Commons Attribution - Pas d'Utilisation Commerciale - Pas de Modification 4.0 International. 


\section{The Literal and the Metaphoric: Paradoxes of Figuration in the Work of Janet Frame}

This essay attempts to address Janet Frame's fondness for strategies of literal expression, a formal aspect of her work often pinpointed by critics but never examined systematically, perhaps because it displays a mercurial quality, inseparable from the author's wit, which resists easy classification. What can be established at any rate is that Frame's leaning towards literality cannot be dissociated from her interest in metaphor - rather as if the literal, by virtue of constituting the ground zero of metaphor, implicitly pointed to further layers of meaning subliminally encoded in her texts. Thus it is argued that the literal in Frame tends to gesture towards its equivalent in metaphor, and vice versa, in a way which can be correlated with her thematic preoccupation with another shift of levels, occurring whenever she stages a creative personality keen to transform the ontological given provided by the real in terms of intuited correspondences in a more visionary dimension.

In a letter to Charles Brasch (dated 2 January 1964), in which she tries to address a reviewer's complaint that she has a "weakness for metaphor; something must always be compared" (Gordon and Harold 11; also quoted in King 268), ${ }^{1}$ Janet Frame readily admits that she may well be unable or "not equipped" to achieve "a pure literary style." This comes across as an ambiguous gesture of self-deprecation, since she seems all too willing to concede that she is "a bad novelist" (12), whilst nonetheless vindicating her personal writing style in the following manner:

I'm afraid I breathe metaphors, mostly bad or indifferent; it is the obsession with images that prompts me to write. I know that the path to good prose isn't necessarily tangled with metaphors; it can be clearer, more serviceable, more beautiful if the wayside is bare; it can have a dignity and strength which no images blossoming in the hedgerows can provide. I don't think I'm equipped to operate the verbal DDT. I can aim to be more disciplined, less indulgent with my images, but they are the basis of my life and my need to write, and they all have meaning. (11-12; Frame's emphases) ${ }^{2}$

It is of course ironic that this declaration, in which stylistic discipline is acknowledged as a desirable (if remote) objective, should be couched in the form of an extended metaphor, itself growing untidily on the "wayside" of "the path to good prose." Without wishing to ascribe to reviewers and critics a power of influence that they never had on Frame, it is tempting to consider that the imperative of sobriety was felt to be strong enough for her to attempt an application of "the verbal DDT" on some patches of her work, from which the weeds of images were consequently removed. Perhaps the author's fondness for literal expression, which coexists in her texts with her unmistakeable metaphoric developments, can be understood as an aspect of her desire to tread a "more serviceable" path of writing, though even then,

1. This is an instance of Frame's tendency to quote approximately, most probably from memory; Owen Leeming's actual words, in his Landfall review of Scented Gardens for the Blind, suggest that "everything must be seen in terms of something else" (Leeming 388).

2. Editors' note: See Delrez's review of the Frame/Brasch correspondence at the end of this volume. 
in a typical example of her ability to have her cake and eat it, she always makes sure that it will lead to meaning.

In all likelihood Janet Frame's predilection for strategies of literal representation constitutes a facet of her overall fascination with language, which goes back in time to her earliest exposure to the frustrating complexities of human expression. In her autobiography she memorably records the sense of betrayal that she experienced on the occasion of a childhood visit at the dentist's, as the nurse invited her to "smell the pretty pink towel" in order to anaesthetise her prior to the extraction of a tooth. Years after the event, the adult narrator remembers her disbelief that the words had been used to trick her into compliance, "that they had not really meant 'Smell the pretty pink towel,' but 'I'm going to put you to sleep while I take your tooth out.' How could that have been?" (Autobiography 23). There is clearly a sense in which the capacity for deception is here displaced from the human agent onto the object of language itself, which is suddenly and catastrophically found not to "really" mean what it says. The child Janet thus evinces a form of epistemological gullibility, implying once again that there may be such a thing as "pure" or objective language - one that would encapsulate some degree at least of unadulterated truth, though both the language and the truth seem to have been lost, perhaps as a condition of human existence. It is arguably a paradox that somebody like Frame, who achieved such proficiency in metaphorical figuration in her later career as a novelist, may nonetheless have retained something of this instinctive conviction that literality carries a promise of referential truthfulness, as if she believed in the possibility of extracting herself from the human muddle through the gesturing towards a language seen to precede ordinary or consensual formulation. This at any rate would be in keeping with the definition of "literal language" offered in Martin Gray's Dictionary of Literary Terms, where it is presented as the sort of language that is "used exactly, in its most precise and limited sense"; so that the literal meaning of a statement is identified as "its most exact, precise and limited meaning, without attention to secondary or symbolic meanings, metaphoric overtones, nuances or ironies" (Gray 114).

My suggestion is that Frame's use of the literal conforms to, and at the same time interestingly departs from, this admittedly formulaic conception, as it certainly accommodates a range of "nuances or ironies" probably as wide as the spectrum of her literalisms. This much is adumbrated by John Thieme when he points out, in his essay in this volume, that Frame typically favours "a mode of representation that conflates the literal and the analogical to a point where they become indistinguishable" (79-80). It is worth pondering the manner governing this unusual yoking of opposites, which is subordinated in her work to a variety of creative intentions. In almost every instance the literal in Frame is linked to her ubiquitous sense of humour, of a sort which privileges the resources of understatement since, by courting literality, she purports to say less, sometimes much less, in order to mean more, indeed a good deal more. Clearly this "bare essentiality of style," combined with "a daring use of language" (Mattei 54), is likely to be manifest as early as The Lagoon and Other Stories inasmuch as this, Frame's earliest published volume, represents a first step towards the construction of a fully realised system of meaning, so that one expects the author to stick here to a simplicity of expression that may well prove deceptive. Such an appearance of simplicity is for example evident when the author's propensity for 
understatement takes the form of an ostensible acceptance of the routines of idiomatic expression, in a way which nevertheless invokes an ulterior level of signification - as when a narrator's informal interjection, "just fancy" (Lagoon 47), simultaneously reads like an exhortation to exercise one's imagination.

Thus Frame's literality will frequently consist of a punning exploitation of the suggestive resonances of a dead metaphor. Her wish to revive a threadbare language is of course apparent throughout in her war against cliché, as indeed in her distaste for "the collective euphemization of death" (Bazin 20), in which meaning is found to be evaded rather than enhanced. But there are times when her treatment of dead metaphors is itself literal, as in her novel The Rainbirds which tells the story of a man called Godfrey, certified dead after a car accident and then resuscitated, even within the morgue, as he suddenly emerges from his comatose condition. The event is deemed sufficiently "topical" to justify the interest of a foreign news agency wishing to give it international coverage through the intervention of a ghost writer (see Yellow Flowers 201). Clearly Frame cannot resist the fun of considering the life-story of a revenant like Godfrey as material produced by a ghost writer, in a typical case of literalism whereby she pours new meaning into a phrase felt to have exhausted its metaphoric potential. This tendency for words to extend their meaning through symbolic association, and then to cease to seem figurative as an effect of semantic attrition, is of course a common fact of human language itself. What is arresting about Frame's treatment of this phenomenon is that she attempts to revive used language not by means of further symbolic extensions, but on the contrary by considering the letter of the idiom, which is then rehearsed from within. Thus the inference in this case is that a ghost writer is indeed likely to produce "dead" language as part of an inferior, journalistic literary endeavour which is implicitly contrasted to literature in its more noble forms, and therefore also, albeit indirectly, to Frame's work itself. ${ }^{3}$

It can be shown that Frame's inclination to literal punning is directly correlated to the felt importance of her main concerns, among which the demands of the creative imagination take pride of place. A paradigmatic example is provided in The Edge of the Alphabet, in which the personality of a staid character - who comes across as lacking in any kind of explorative drive - is signified through the fact that he finds occupation in a stationery shop. The pun in this case relies on the phonetic proximity between "stationery" and "stationary," so that both terms are taken metonymically to designate a stay-at-home kind of mentality. The same preoccupation with shackles of the mind, coded in terms of static living, is again registered, in a story like "The Reservoir," through the labelling of poliomyelitis as "infantile paralysis" (Reservoir 14), a phrase which reveals the children protagonists' fear of finding themselves imprisoned in an iron lung and, by association, in the mental universe of adults where the roaming imagination is penalised since, as they learn from their trip to the Reservoir, "Trespassers Will Be ProsecuteD" (16). That the journeys through life and open space may not always eventuate in the expected enlargement of perspective is repeatedly indicated in Frame's work through ironic naming of the public conveyances

3. It is not unusual for Frame's fiction to contain a number of more or less distorted images of itself within the text, thus creating a textual hierarchy where truly imaginative fiction reigns supreme over debased forms of writing figured under the guise of journalism (see Delrez "Conquest of Surfaces"). 
resorted to by her characters: in A State of Siege, Malfred initiates her trip of liberation by boarding a train actually called "the Limited" (Siege 33).

By contrast, though no less literally, in the autobiography Frame evokes the creative streak running in her own family through the reference to the "exquisite embroidery, knitting, tatting, crochet" - a range of skills known in the family as "fancy-work," produced by generations of her ancestors (Autobiography 7). By association, Frame's own writing (with its particular patterning) also ranks within the same category of objectified "fancywork," especially since the term is connotatively linked to the quality of imagination that Janet is so keen to cultivate. She certainly thinks of the creations of others in terms of an "accumulation of artistic weavings," which form a fascinating backdrop to her own contribution to "the shared carpet" (307). Hence, of course, the ironic resonance of the question repeatedly asked by Patrick Reilly, a fellow tenant at the house Janet would occupy in Clapham Common, as a way of finding out whether she has a boyfriend: "By the way, are you fancy free?" (305). This image of weaving, substituting for the activity of patterning a literary text, notably extends into Owls Do Cry where it operates as an ordinary metaphor. In the autobiography, the originality of the treatment of this motif derives from Frame's decision to provide an archaeological excavation of the metaphor, as it were, taking us back to the originary moment when, in the author's mental universe, "fancy" still denoted manual work (i.e., actual embroidery) rather than an intellectual creative endeavour. This should alert us to a twofold consequence: first, that the literal approach to a term may always already contain, however seminally, some metaphoric potential; and second, that the attempt to return to any pre-metaphoric status of a word has structurally a lot in common with the search for the "root," or the etymological origin, of that word.

Now it so happens that Frame at times does play with etymologies, as when she has a character muse on "the topic of guests in the house," which clearly stands metaphorically, in her novel Living in the Maniototo, for the related condition of entertaining "guests in the house of fiction" - a clear indication that her primary preoccupation here remains the exploration of the processes, psychological and metaphysical, of the creative imagination. In this context she marvels at "the richness of meaning within the words 'guest' and 'host,' with a guest as originally a host, a stranger, hostis, an enemy, a host as a guest, a multitude of men, women, angels; planets, stars; a guest as parasite sheltered by the host, the host a sacrifice and ultimately a blessed food" (Maniototo 133). The least which one can say is that the metaphor proliferates in this passage where the artistic vocation is envisaged progressively as embattled, self-negating, and even sacrificial; while the creative personality is projected as riddled with aspects of its own differance. Interestingly, then, the recourse to etymology, far from pursuing the purpose of simplification, instead becomes instrumental in decentring semantic expectation - indeed one of the lessons of the search is that the notions of "host" and "guest" can be considered to be interchangeable, so that the novelist herself emerges as a fictional creation within her own work. The matter is complicated even further when, in the same passage, the protagonist remembers the time in her childhood when her teacher during sewing class assigned the pupils to make "a small hem-stitched towel" meant for hypothetical guests, which she, "mishearing, believed for many years to be a 'guess towel" (133). 
Clearly this reintroduces the theme of weaving or stitching in connection with the writing process, but with the additional suggestion that "fancywork" can be confused or equated with "guesswork," while it is also the case that there is no guessing the consequences of playing host to the guests of fiction within oneself. Thus attention is drawn to the heuristic serendipity, indeed to the perilous courting of the unknown informing the adventure inherent in all art.

It is noteworthy that the conflation of terms such as "guest" and "guess" depends less on a deliberate creative decision than on a chance encounter consecutive upon a case of mishearing. This sort of phonetic malapropism is typical of what Frame calls the climate of childhood, ${ }^{4}$ and the early chapters of the autobiography are full of amusing anecdotes relating to the child Janet's linguistic naiveté in this respect. However, it is characteristic of the passage from autobiographical to fictional material that, in the novels, such phonetic misreading of language is made functional within the meaning-making economy of the text. An obvious case in point is supplied in Intensive Care, where a character called Milly is presented as a mentally deficient young woman of nearly twenty-six who straddles temporalities and comes across as a grown adult saddled with the mind of a child. A major dimension of this intriguing case of characterisation is that Milly, ostensibly deprived of "reading readiness" and "afraid of words" as she is, approaches writing as a "mixed up" code which is phonetically accurate but scripturally erratic in a way that points to alternative avenues of wisdom. By this token it is clear that the climate of childhood is seen to encode its own universe of meaning, one that is ironically pitted against the familiar conceptions associated with normalcy and adulthood. Thus Milly refers to other people's insistence that one should strive to be "doll-normill," in a way which signals her astute apprehension of the dehumanising dangers lurking at the heart of conformism ${ }^{5}-$ which places her as somebody who is, in many respects, "above normill" (Intensive Care 235). Her phonetic spelling then proves dichotomous, since it simultaneously betrays her learning difficulties and her relative proficiency in a creative medium redolent with incisive insights. Arguably, this bifurcation of understanding parallels the similar dialectics at work in Frame's leaning towards literal expression, while the latter is made apposite, in a novel like Intensive Care, to Milly's interest in counting and mathematics, pursued in the conviction that there is cleanliness and "no sickness in numbers" (32), indeed as if "numbers were the language" (178), or at least an ambivalent mode of notation situated both beneath and beyond natural languages.

It may look as if this tentative reflection on Frame's literalism stands in excess of the concerns developed in The Lagoon and Other Stories, by all accounts a juvenile work written at a time when the author was still unable to identify with her vocation in a professional capacity, let alone thematise this in the metafictional manner that would characterize her later oewvre. Yet it is clear that the creative predicament already constitutes a thematic touchstone in a sizeable proportion of these early stories, not only in the obvious "Jan Godfrey," "Miss Gibson and the Lumber Room," or "My

\footnotetext{
4. For an exploration of this creative disposition of children, seen as a primordial rehearsal of actual artistic activity, see Bazin and Braun (2010).

5. Consider the further irony implicit in the judgement ventured by Milly's mother, to the effect that, at nearly twenty-six, "a-doll-essence is upon her" (Frame Intensive Care, 237).
} 
Last Story." Certainly the childish inclination to "talk in code" (Lagoon 25) is acknowledged also, in "Keel and Kool," "The Secret," and elsewhere. Interestingly, this is linked at times to the sort of literalism practised by children whose lifeexperience tends to be governed by their unformed verbal imagination. For example, in "A Note on the Russian War," it is mentioned as a matter of course that "you put the buttercups under your chin to see if you love butter," never mind if the exercise is made redundant by the knowledge that everyone "love[s] butter anyway so what's the use" (152). In the same story a similarly literal cast of mind is displayed by the narrator when she considers the War of the Roses as an actual struggle for prominence waged in a flower garden as the summer days emerge "out of the spring." Already, too, this apparent linguistic simplicity conceals a profound ontological overhaul since the War of the Roses, just like "the Hundred Years" or "the Great War," is made to signify the revolutionary transformation which occurs in the passage inwards, into the "fence of being" (152) enclosing the limitless scope of the individual imagination in full swing. We shall see in what follows that the now familiar tropes - of literal apprehension and creative misreading - crucially inform the story entitled "Spirit," one of the shortest tales, and at first sight one of the lightest, in the collection.

"Spirit" is an amusing dystopian fable ${ }^{7}$ designed as a brief surreal dialogue between the ghost of a man called Harry, who has just died "sunning [himself] in the garden" 8 and is now seeking admittance to Eden, and an anonymous interrogator who ominously addresses his guest as "Spirit 350" and breezily assures him that their conversation is "just a matter of form," necessary if "suitable eternal places" (89) are to be found for the clients. The disquieting tone of this exchange, an aspect of Frame's dark humour, derives from the protagonists' evident unfamiliarity with each other's respective universes, as the god-like warden reveals his ignorance of some of the more basic traits of human life, like the fact that people "have names," read newspapers, and sometimes enjoy "music and dancing" (90). The supercilious, Cerberus-like figure officiating at the gates of paradise prefigures a novella such as "Snowman Snowman" where Frame will again construct a character who behaves like "a visitor from outer space" (Snowman 43), in that he occupies a perspective purged of "the human habit of deception" (88) - so that it can be contrasted with the more habitual "human focus" (12). In "Spirit," this alienation effect culminates in the grim logic of the story's denouement, when Harry is offered "a nice permanently juicy leaf, small but quite comfortable" (Lagoon 91), to serve as his eternal home. He thus appears to be the victim of a disastrous misunderstanding, ostensibly because his own narration of his short stint on earth made it impossible for the unprejudiced warden to distinguish between his approach to experience and that of a contentedly munching slug. Harry is then despatched into eternity with the consoling words that, being dead

6. See Braun (2007) for an examination of "Jan Godfrey" as a representation of the writer grappling with the prospect of artistic failure, in a way which sets a pattern for similar evocations in later works by Frame.

7. See Allan Weiss's essay in this volume for an interesting reading of "Spirit" as a "modern" fable.

8. Such an anti-heroic death possibly points proleptically to Frame's characteristic depiction of the sun as a frightening dissolver of identities, a "symbol for [the] meeting of presence and absence, object and shadow, I and notI" (Delbaere 172), as it would be employed in Daughter Buffalo for example. This overturning of received connotations - the darkness of shadows is valorised positively whilst the sun leads straight to hell - can be traced back to the work of William Blake, which constitutes an identifiable shaping influence on some of the Lagoon stories (see Mortelette 79$80)$. 
already, he will no longer be bothered by big "swooping blackbirds" (91) - a literal translation by the warden of Harry's earlier identification of man's worst enemy as "a big black death [that] swoops down from the skies at any moment to carry us away" (90).

The story could be read variously as a modern-day exploration of the deficiencies of human language as a means of communication, as a kafkaesque study of extreme alienation from a suddenly defamiliarised environment, or even as a repudiation of the spurious consolations offered by religious eschatologies. However, those lines of interpretation recede as one becomes aware of a further level of irony, concealed behind the flippant façade of the tale, and apparent in the suggestion that the warden's decision is not after all entirely illegitimate if Harry's "brief outline" of his own life is understood literally - and yet creatively. At the same time the verdict appears to be based on an implicit hierarchy of value whereby some people's choice of a static existence relegates them to some less-than-dignified subhuman status. Clearly, Harry's autobiographical narration makes him vulnerable to this sort of condemnation for he endorses in death his own youthful renunciation of the dream of becoming "an inventor or explorer or sea captain" (89), when he forsook the search for "imaginative recognitions" (Frame "Departures," 87) and opted instead for a daily "round of eating and sleeping and other pleasures." He thus keeps on embracing the mediocre ideals specific to "creatures of habit" for whom every day is spent "mostly just going backwards and forwards doing this and that." There is then a solid continuity of mode between Harry's "simple existence" (Lagoon 90) on earth and his reward in the form of a life-after-death on a leaf guaranteed to contain "aeons and aeons of juice" (91). The "last judgement" provided by the warden thus interestingly depends on an ambivalent mode of evaluation, since on the one hand the verdict comes across as the outcome of his literal misapprehension of the particulars of human existence, which he takes to be at best "a little out of the ordinary" (90); while on the other hand it fittingly expresses and prefigures the condemnation of "stationary" living that would continue in Frame's subsequent work. Nor is "Spirit" alone, in the collection, in circumscribing this early thematic preoccupation with the pointlessness of a circular existence, since a story like "The Day of the Sheep" also stages the disorientation of a character who keeps "going backwards and forwards" in the house, forever repeating the same "little irrelevant journeys" (74). Clearly this story contains a hint that a "way out" of this existential imprisonment may be devised through the invention of a properly creative code, one that would serve the purpose of penetrating the "secret" of existence, inasmuch as the protagonist's mental muddle is ascribed to her lack of a "grammar of journeys" (69).

Similarly in "Spirit" Harry refers to his life experience in terms of a succession of missed opportunities, starting with his attendance as a child of "some kind of school" where he learned "writing and spelling" alongside "profit and loss" (89), in what appears to be a frustrated attempt at mastering the kind of transformative language whereby loss may translate as a kind of profit - as happens for example in Danghter Buffalo where writing begins to be viewed as a special instrument deliberately conceived for the purpose of retrieving eclipsed realities. It seems obvious, however, that by contrast Harry's narrative of self sticks to a conformist pattern of experience, and by implication to a rudimentary scale of representation, which serves to delineate, 
albeit obliquely, the ontological limits that a more imaginative mind may wish to push back and probe. As we have seen, Frame tends to include within her own work the sort of constrained perspective that needs to be rehearsed creatively. Although, in this case, the human protagonist can hardly be viewed as an avatar of the "inferior" artist or as an exponent of journalistic writing, it is nonetheless clear that, whatever doubts the warden may have entertained as to the appropriateness of his chosen brand of infinity, these are finally dispelled, and Harry seals his fate, when the latter dismisses the attempts of artists, who are "always trying to leave their mark on the world" (9091), as epitomising the vanity of human wishes: "It's like the wind and the sand ha ha" (91).

As Allan Weiss also observes, "Spirit" thus finds its place among the more satirical items in Frame's corpus, which ruthlessly expose what she views as a spiritual deficit consequent upon the lazy materialism of Western societies. Accordingly the story's conclusion comes across as an expression of anger, even of contempt, for those who betray her lofty conception of a questing humanity. Yet it is typical of Frame's remedial disposition that the punishment inflicted on Harry, implacable and neverending though it may seem, also contains the seeds of his redemption. If it is the prerogative of artists to reject conventions and to engage in pathfinding endeavours, thus literally making "some sort of a trail," ironically Spirit 350 in his new circular life as a slug will leave behind him slimy secretions which, intersecting on his leaf, will form "a little permanent silver patch of [his] own" (91). This will constitute a personal achievement after all, while the story ends on an understated affirmation of the permanence of creation - which represents some progress over Harry's earlier karma. Thus "Spirit" ends on a note which in many ways resembles and anticipates on the "strategy of ostensible closure" (Delrez Utopia, 180) which will become a favourite device in a majority of Frame's works to come. This typically consists of an anticlimactic conclusion, often the result of a shift in perspective, which jolts the reader into a keen awareness of what is lost through the restoration of a normative outlook in the wake of the text's explorations; while at the same time this diminished coda still contains ironic traces which subliminally gesture towards the permanence of loss, thus importantly reinscribing within the norm that which it tends to sacrifice. This narrative strategy, manifest in novels like Scented Gardens for the Blind, The Adaptable Man and The Rainbirds, is clearly struggling to emerge in some of the Lagoon stories, including "Dossy," "The Day of the Sheep," "My Last Story," and others.

In "Spirit," the apparently dead-pan ending must similarly be correlated with a dimension of suppressed meaning which will become all the more resonant if one reconstitutes, across the width of Frame's work, the genealogy of the image central to the tale's close. Indeed Harry's "little permanent silver patch" presents affinities with the metaphor of the silkworms, which again associates a grub with the production of beauty, and which will recur in time from one text to the next. In the autobiography Frame, reminiscing about the time when she was staying with her mentor Frank Sargeson, evokes her first observation of the life-cycle of the silkworms together with "the golden thread of plaited silk" (Autobiography 267) in which it eventuates. Then the same material is rehearsed repeatedly in the fiction, where it is metaphorised much more extensively. Thus the theme will be exploited in a short story like "The Silkworms," which was withheld from publication in the author's lifetime because of 
its lampooning of Sargeson, and was therefore released posthumously. Here the relevance to artistic creation is emphasised, as the human manager of the silkworms' life and death is a professional writer who fancies himself as a "God looking from [his] door upon completeness" "'Silkworms" 113). The same bid for exhaustiveness of perception is again apparent in Daughter Buffalo where an artistic character indicates his admiration of the dedication manifested by the silkworms which never stop feeding, not even in the night, for "eating is their life" and "they must devour the mulberry bush." It is not only, then, that the grubs are "pure sensation" - for "they recoil, quivering," at the slightest touch, thus allegorising the artist's sensitivity; but their preternatural greed also hints at the Midas touch of the novelist who will seize upon any aspect of lived experience as potential provender for his pen, prior to transforming it. Incidentally this view provides a confirmation of the observation, in the autobiography, that "the silkworms were eating for dear life" (Autobiography 266; Frame's emphasis), an idiomatic phrase that can be understood literally in the context of an aesthetic reflection in which the value of life is seen to be fully fathomed only when reviewed through fiction. Thus, in the novel, the "unravelled shroud that is a spool of silk" is admired like "a trophy of life and death." Somehow this betokens the death of the writer himself, who meditates: "Were I dead, waiting to be buried, lying in my allotted drawer in the mortuary, I should hear the silkworms eating through the ice to reach me" (Danghter Buffalo 30). This is typical of the reflexive drive of Frame's work which constantly aspires to include itself, via its metafictional dimension, in the transformation of (auto)biographical material that it ostensibly performs. Perhaps this constitutes an aporia - an impossibility in logical terms - meant to be inseparable from the miracle of fiction itself. Indeed the novelist-character in this book hardly distinguishes between his assimilation of others and of himself: "I have consumed many deaths in a mountainous banquet set before me. I have devoured them all until reaching my own death I achieve the miracle of metamorphosis, round and round the mulberry tree on the cold and frosty morning of language" (31). ${ }^{9}$

All of this has relevance to "Spirit" where Harry, in his moronic ignorance of the creative dimensions of existence, behaves like a silkworm which "wave[s] its head about like an idiot, and drool[s] golden threads of silk" (Daughter Buffalo 30). In other words, the fact that he himself fails to penetrate the further meaning - "the secret" of his own life does not prevent his narrative from being susceptible of recuperation at a superior level enjoined upon him by a higher authority. This is why it is crucial to this reading of the story that the warden be acknowledged not simply as a fellow human soul, or as an "experienced spirit [who] seeks to initiate the recent arrival into his new condition" (Weiss 50), but rather as "a divine manifestation" (Gwynne 14), ${ }^{10}$ indeed a demiurgic power endowed with the ability to revise the parameters of the story produced by his interlocutor. Thus, in keeping with the infinite rehearsal of finite material staged in Frame's work, the warden's smug offer of eternity can be taken

9. It is striking that a similar conception is taken up in Frame's correspondence of around that time since, in a letter to Bill Brown (dated June 1973) where she evokes her grief at the death of Charles Brasch, she writes: "What a force life becomes when people die. We do feed on the dead, just as they feed on us. Who said eating people was wrong?" (Gordon and Harold 54).

10. This phrase is offered in the context of a discussion of another story, "An Interlude in Hell," which is construed as an allegory of the afterlife similar to that provided in "Spirit." 
literally, as a promise that posterity will indeed begin when "dear life" is subjected to revision by the creative artist. By this token Harry's slimy sliding "up and down" his leaf (Lagoon 91) can be interpreted, within the terms of Frame's literal mode of notation, as an indication of incontestable progress over his earlier static living, so that his own limited narrative becomes creatively decentred, and the implicit fatalism of Frame's satire is effectively dislodged. "Spirit" can then be said to be inscribed within what Gwynne calls a "plural aesthetic ambition" (Gwynne 17) pursued by the author, since in the light of its metafictional dimension the narrative can be read dichotomously as both a realist commentary and an allegory on the transcendence of creation. One can then only agree with those critics of Janet Frame who seek to bypass a duality of interpretation distinguishing too neatly between "this" and "that" world (see Weiss 43-45), in view of her conviction that even the most disappointing and unimaginative narration structurally calls for an improved variant of itself, and so on ad infinitum. Her favourite theme, the transformation of fact into fiction, and of factual description into something else bordering on poetry, is approached in such a way that the two extremes of the polarity - truth and invention, or prose and poetry are caught in a dialectical relationship with one another. This dialectical process is notably apparent, in "Spirit," through the fact that Harry's narration of his life, for all its insufficiencies, nonetheless contains metaphoric turns of phrase - such as his description of death as a "big black [bird that] swoops down from the skies" (90) which seem inconsistent with his usual flatness of expression and which therefore already point to the higher level of realisation to which the story's material must be subjected - encoded as it is in the image of the "silver patch." Likewise, the reference to Shakespeare's Hamlet, "in form and moving how like an angel," however misquoted and distanced through the tag "they say" (91), constitutes an early breach in the smooth surface of a story awaiting further transformation and complexification. Thus it is fascinating to note that, inasmuch as Frame's literal turns of phrase gesture towards metaphor and vice versa, an equivalence is established between form and content also, as language, too, is approached as a shifting medium open to constant revision

Marc DELREZ, University of Liège

\section{Works Cited}

BAZIN, Claire. "Janet Frame: 'Keel and Kool' and Autobiogra/fiction." Commonwealth Essays and Studies 29.2 (Spring 2007): 19-28.

BAZIN, Claire, and Alice BRAUn. Janet Frame, The Lagoon and Other Stories: Naissance d'une oewure. Paris: Presses Universitaires de France/CNED, 2010. 54-92.

Braun, Alice. "The Author at Work: Two Short Stories by Janet Frame." Commonwealth Essays and Studies 30.1 (Autumn 2007): 93-103.

Delbaere, Jeanne. "Turnlung in the Noon Sun: An Analysis of Daughter Buffalo." The Ring of Fire: Essays on Janet Frame. Ed. Jeanne Delbaere. Sydney: Dangaroo Press, 1992. 161-176.

Delrez, Marc. "'Conquest of Surfaces': Aesthetic and Political Violence in the Work of Janet Frame." Frameworks: Contemporary Criticism on Janet Frame. Ed. Jan Cronin and Simone Drichel. Amsterdam \& New York: Rodopi, 2009 (Cross/Cultures 110). 135-153.

—. Manifold Utopia: The Novels of Janet Frame. Amsterdam \& New York: Rodopi, 2002.

FrAME, Janet. An Autobiography. 1989. New York: Braziller, 1991.

-. "Departures and Returns." Writers in East-West Encounter. Ed. Guy Amirthanayagam. London: Macmillan, 1982. 85-94. 
-. The Edge of the Alphabet. New York: Braziller, 1962.

—. Intensive Care. New York: Braziller, 1970.

—. The Lagoon and Other Stories. 1950. London: Bloomsbury, 1997.

—. Living in the Maniototo. New York: Braziller, 1979.

—. Owls Do Cry. London: The Women's Press, 1992.

—. The Reservoir: Stories and Sketches. New York: Braziller, 1963.

—. "The Silkworms." Granta: The Magazine of New Writing 105 (2009): 113-122.

-. Snowman Snowman: Fables and Fantasies. New York: Braziller, 1963.

-. A State of Siege. Christchurch: Pegasus, 1967.

-. Yellow Flowers in the Antipodean Room. New York: Braziller, 1969.

GORDON, Pamela, and Denis HAROLD, eds. Dear Charles Dear Janet: Frame \& Brasch in Correspondence. Auckland: The Holloway Press, 2010.

Gray, Martin. A Dictionary of Literary Terms. Harlow: Longman, 1990.

GWYNNE, Joel. "Inertia Creeps: Hesitancy in Janet Frame's Short Fiction." Commonwealth Essays and Studies 29.2 (Spring 2007): 7-18.

KING, Michael. Wrestling with the Angel: A Life of Janet Frame. Washington, DC: Counterpoint, 2000. LEEMING, Owen. Review of Scented Gardens for the Blind. Landfall 17 (December 1963): 386-389.

MatTeI, Anna Grazia. "Two Sheep: A Fable." The Ring of Fire: Essays on Janet Frame. Ed. Jeanne Delbaere. Sydney: Dangaroo Press, 1992. 54-62.

MORTELETTE, Ivane. Janet Frame: The Lagoon and Other Stories. Paris: Atlande, 2010. 